Tropospheric layering

J. Brioude

\title{
Evidence of tropospheric layering: interleaved stratospheric and planetary boundary layer intrusions
}

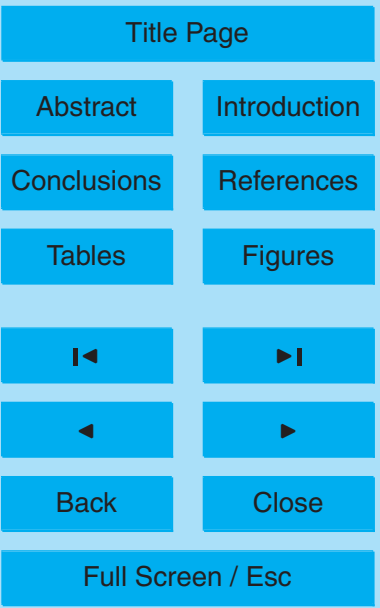

J. Brioude ${ }^{1,{ }^{*}}$, J.-P. Cammas ${ }^{1}$, R. M. Zbinden ${ }^{1}$, and V. Thouret ${ }^{1}$

${ }^{1}$ Laboratoire d'Aérologie, UMR 5560, Observatoire Midi-Pyrénées, Toulouse, France now at: NOAA Earth System Research Laboratory, Boulder, Colorado, USA

Received: 4 October 2006 - Accepted: 17 January 2007 - Published: 23 January 2007

Correspondence to: J. Brioude (brij@aero.obs-mip.fr) 


\section{Abstract}

We present a case study of interleaving in the free troposphere of 4 layers of nontropospheric origin, with emphasis on their residence time in the troposphere. Two layers are stratospheric intrusions at 4.7 and $2.2 \mathrm{~km}$ altitude with residence times of 5 about 2 and 6.5 days, respectively. The two other layers at 7 and $3 \mathrm{~km}$ altitude were extracted from the maritime planetary boundary layer by warm conveyor belts associated with two extratropical lows and have residence times of about 2 and 5.75 days, respectively. The event took place over Frankfurt (Germany) in February 2002 and was observed by a commercial airliner from the MOZAIC programme with measurements of ozone, carbon monoxide and water vapour. Origins and residence times in the troposphere of these layers are documented with a trajectory and particle dispersion model. The combination of forward and backward simulations of the Lagrangian model allows the period of time during which the residence time can be assessed to be longer, as shown by the capture of the stratospheric-origin signature of the lowest tropopause fold just about to be completely mixed above the planetary boundary layer. This case study is of interest for atmospheric chemistry because it emphasizes the importance of coherent airstreams that produce laminae in the free troposphere and that contribute to the average tropospheric ozone. The interleaving of these 4 layers also provides the conditions for a valuable case study for the validation of global chemistry transport models used to perform tropospheric ozone budgets.

\section{Introduction}

The layered structure of the extratropical troposphere and its ubiquity have been shown with aircraft insitu measurements of ozone and water vapour (e.g., Newell et al., 1999; Thouret et al., 2000; Colette and Ancellet, 2005). The main class of these layers is of stratospheric origin and is characterized by a positive ozone anomaly, a negative humidity anomaly, a mean thickness of $860 \mathrm{~m}$ and a mean volume in the troposphere

Tropospheric layering

J. Brioude

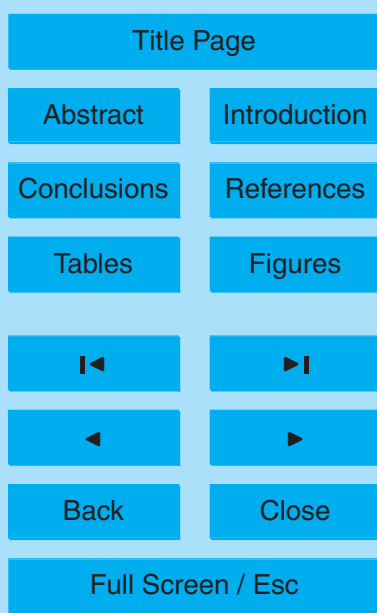

Printer-friendly Version

Interactive Discussion 
of $11 \%$ (Newell et al., 1999). A source region of these layers are the jet-front systems associated with extratropical lows (Esler et al., 2003). Wernli and Davies (1997) have shown that coherent ensembles of trajectories characterize the dynamics of extratropical lows. Ahead of the cold front, the warm conveyor belt (WCB) is characterized by

5 rapid ascent of particles to mid-tropospheric levels over the warm surface front and then by poleward and eastward transport. The transport in the WCB is considered as the main transport mechanism from the boundary layer to the upper troposphere in midlatitudes (Stohl, 2001; Cooper et al., 2001; Esler et al., 2003) and is important for the transport of polluted airmasses (Stohl and Trickl, 1999; Cooper et al., 2002a, 10 2002b; Eckhardt et al., 2004). The dry airstream (DA) is a coherent airstream that descends isentropically from the tropopause region into the middle and lower troposphere towards the centre of the maturing cyclone, and transports dry and possibly stratospheric-origin air masses (Wernli, 1997; Cooper et al., 1998; Stohl and Trickl, 1999). The irreversible transport from the stratosphere to the troposphere is related 15 to fine scale structures like tropopause folds and filaments (Danielsen, 1968; Shapiro, 1978; Vaughan et al., 1994; Appenzeller et al., 1996) which results in laminar distribution of chemical species in vertical profiles (Newell et al., 1999; Bithell et al., 1999; Curtius et al., 2001; Esler et al., 2003). Stratospheric intrusions are stretched and filamented to smaller and smaller scale structure and are interleaved with tropospheric airmasses while they travel in cyclonic and anticyclonic disturbances (Gray et al., 1994). The irreversible mixing of stratospheric airmasses into the troposphere is influenced by turbulent mixing, dissipative radiative effects and molecular diffusion (Shapiro, 1980; Appenzeller et al., 1996; Forster and Wirth, 2000).

As shown by Wernli and Bourqui (2002) and Stohl et al. (2003), pathways of crosstropopause exchange of the air particles, their vertical penetration and residence time in the troposphere are the most relevant aspects of stratosphere-troposphere exchanges. Observational studies have shown that the residence time of stratospheric intrusions into the troposphere could be as long as a few days. Using an isentropic trajectory analysis on ozonesonde data, Bithell et al. (2000) evaluated the residence time

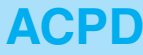

7, 1119-1142, 2007

Tropospheric layering

J. Brioude

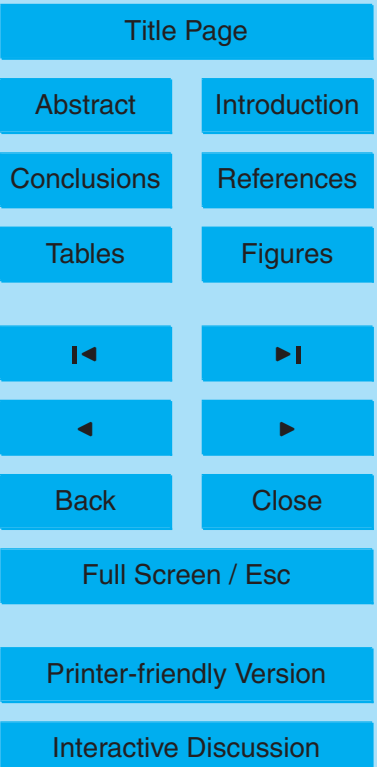

EGU 
of stratospheric intrusions into the troposphere of about 10 days. Transport processes can bring together air masses initially situated across the two sides of the cold front. Cooper et al. (2004) have studied the mixing between a deep stratospheric intrusion and air masses processed by a WCB. They have shown that $50 \%$ of the stratospheric 5 airmass is mixed with airmasses of the WCB, which affects the $\mathrm{OH}$ radical concentration and the chemical budget of different trace gases (Esler et al., 2001). Chemistry Transport Models (CTMs) have difficulty reproducing the layered structure of the troposphere and simulating the resolution of layers like stratospheric intrusions. Coarse vertical and horizontal resolutions, and the accuracy of parameterizations of turbulent 10 mixing in convective cells and into the boundary layer are main factors on which depends the residence time in CTMs. Bithell et al. (1999) have shown that stratospheric intrusions rapidly collapse to the model grid scale. As a consequence, CTMs do not well reproduce the life cycle of these layering structures, reducing the relevance of chemical simulations for the budget of tropospheric trace gases. Model improvement 15 and model evaluation need well documented case studies. The objective of this paper is to report on an interesting case study during which several kinds of tropospheric layers interleave on to a vertical profile.

Better resolution, increased use of assimilated observations and recent progress in 4D-VAR assimilation techniques have enhanced the quality and the dynamical coherence of operational global-scale analyses, individually and in time series (Rabier et al., 2000; Mahfouf and Rabier, 2000). As a consequence, Lagrangian-based analyses to track the history of air masses are less hampered by the effect of spatial and temporal interpolation of analysed parameters on the computation of advection terms. Such an approach was emphasized in the framework of the STACCATO project (Stratosphere

25 Troposphere Exchange in a Changing Climate on Atmospheric Transport and Oxidation Capacity, Stohl et al., 2003). Recent studies (e.g., Esler et al., 2003; Brioude et al., 2006) have used a Lagrangian-based reverse domain filling (RDF) technique to reconstruct layered structures at small scale in frontal systems. This paper presents such a Lagrangian-based methodology to assess the residence time of tropospheric

Tropospheric layering

J. Brioude

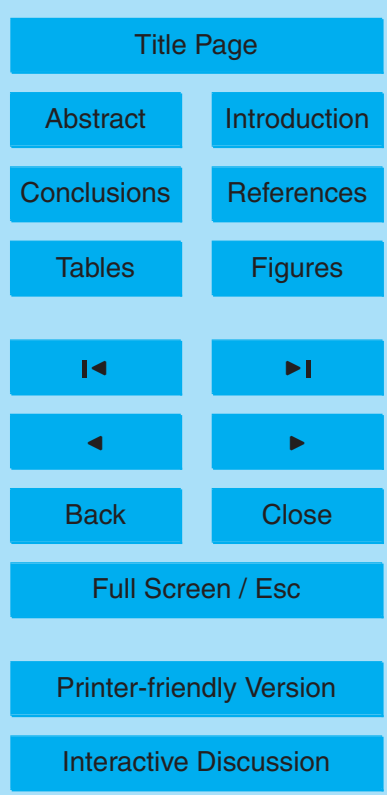

EGU 
layers. Observations come from a vertical profile of ozone, carbon monoxide, and thermodynamical parameters sampled in February 2002 over Frankfurt (Germany) by a commercial airliner participating in to the MOZAIC programme (Measurements of Ozone, Water Vapour, Carbon Monoxide and Nitrogen Oxides by Airbus in-service air5 craft, http://mozaic.aero.obs-mip.fr/web/). The case study involves the interleaving of 4 tropospheric layers, i.e. 2 tropopause folds and 2 warm conveyor belts. The measurements and the modelling techniques are described in Sect. 2. Section 3 presents the results from the lagrangian analysis. Conclusions are drawn in Sect. 4.

\section{Methods and data}

\subsection{Lagrangian calculations}

We use the FLEXPART (version 6.2) Lagrangian particle dispersion model (Stohl and Thomson, 1999; Stohl et al., 2005) to simulate the flow of air and trace the origin of airmasses. Backward transport and dispersion of linear tracers by calculating the trajectories of a multitude of particles produce a cloud of particles that is called a retroplume.

15 FLEXPART is driven by model-level data from the European Centre for Medium-Range Weather Forecasts (ECMWF), with a temporal resolution of $3 \mathrm{~h}$ (analyses at 00:00, 06:00, 12:00, 18:00 UTC; 3-h forecasts at 03:00, 09:00, 15:00, 21:00 UTC), horizontal resolution in latitude and longitude of $1^{\circ}$, and 60 vertical levels. Particles are transported both by the resolved winds and parameterized subgrid motions. FLEXPART parameterizes turbulence in the boundary layer and in the free troposphere by solving Langevin equations (Stohl and Thomson, 1999). FLEXPART uses also a parameterization scheme for convection (Emanuel and Zivkovic-Rothman, 1999). Retroplumes are initiated with sets of 20000 particles released over $1 \mathrm{~h}$ time interval from grid boxes $\left(0.5^{\circ} \times 0.5^{\circ}\right.$ latitude-longitude and $100 \mathrm{~m}$ in height $)$ centered on the MOZAIC aircraft path. The retroplumes are advected backward in time over 10 days. To determine the percentage of a retroplume that originated from the stratosphere and from the plan-

\section{Tropospheric} layering

J. Brioude

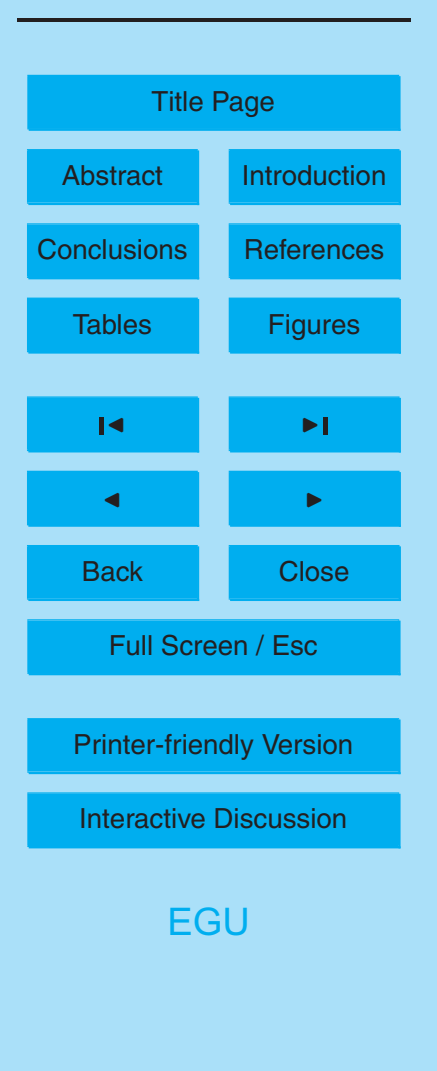


etary boundary layer, the number of end-of-trajectory particles with potential vorticity (PV) larger than 2 pvu and with altitude below the boundary layer height are computed in each grid cell of $3^{\circ}$ in latitude and $5^{\circ}$ in longitude to yield percentages of the retroplume originating in the lowermost stratosphere (called ST) and in the boundary layer 5 (called BL), respectively. A threshold of 2 pvu is used for PV to define the dynamical tropopause. Planetary boundary layer height is determined by the Richardson number (see Stohl et al., 2005 for details). The spreading of trajectories in backward mode makes it difficult to study thermodynamic features which characterize a retroplume at every output time. To tackle the latter difficulty, a cluster analysis of the particle posi10 tions is performed (Stohl et al., 2002; Stohl et al., 2005). It determines the 10 clusters that best characterize the internal three-dimensional distribution of particles in the volume of the retroplume at every output time (see Stohl et al., 2002 for details). The choice of a maximum of ten clusters ensures that a significant mass fraction characterizes each cluster. Dynamics of a retroplume are then characterized by the mean 15 values of positions, PV, and relative humidity of particles belonging to clusters, as well as the number of particles in each cluster.

In the forward mode, a stratospheric ozone tracer is calculated with the FLEXPART model (Stohl et al., 2000; Cooper et al., 2005). Its field is initialized in the model domain and at the model boundaries, and then advected with ECMWF winds within the model domain covering from $120^{\circ} \mathrm{W}$ to $45^{\circ} \mathrm{E}$ and $30^{\circ} \mathrm{N}$ to $81^{\circ} \mathrm{N}$. The FLEXPART run with the forward mode began on 31 January 2002, 01:00 UTC. Criteria used to initialize the stratospheric ozone tracer are $P V \geq 2 \mathrm{pvu}$ and height $\geq 3 \mathrm{~km}$. The condition on height is employed to avoid tagging a tropospheric particle that has a high PV value by diabatic PV production in cloudy areas as a stratospheric-origin particle. Once a particle has gone across a boundary limit of the domain, it is removed from the simulation. Stratospheric particles are given a mass of ozone according to: $M_{\mathrm{O}_{3}}=M_{\text {air }}$.PV.C.48/29 where $C=63.10^{-9} \mathrm{pvu}^{-1}$ is the ratio between the ozone volume mixing ratio and $\mathrm{PV}$ in the stratosphere at this time of the year, $M_{\text {air }}$ is a threshold value that a mass of air entering the model at a grid cell has to reach to create a trajectory particle at a random

\section{Tropospheric} layering

J. Brioude

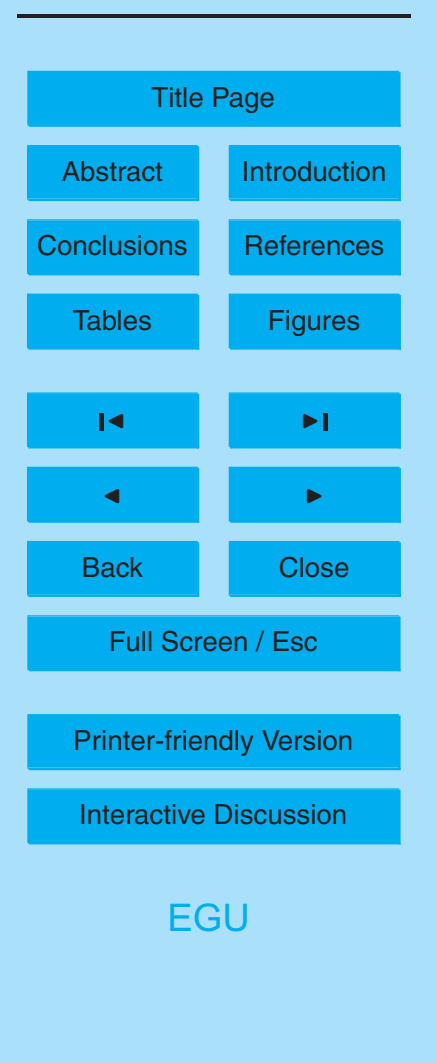


location at the boundary of the grid cell, $P V$ is the PV value at the position of a stratospheric particle and $M_{\mathrm{O}_{3}}$ is the mass of ozone. The factor 48/29 converts from volume mixing ratio to mass mixing ratio. $C$ is taken from Stohl et al. (2000) who found that the average relationship between ozone and PV in the lowermost stratosphere over 5 Europe as determined from ozonesondes was 63ppbv/pvu in February. The stratospheric ozone is treated as a passive tracer, and its distribution in the troposphere is only due to transport from the stratosphere. However, the success of such a method to capture the stratospheric origin of air parcels may be altered by deficiencies in the representation of diffusion in Lagrangian models. For residence times of stratospheric 10 intrusions into the troposphere exceeding a few days, the diffusion in the Lagrangian model may be too large (Stohl et al., 2004) and lead to the loss of the stratosphericorigin character of air masses. To tackle such a difficulty, we present below a method that consists in coupling the forward and backward runs of FLEXPART to reconstruct the stratospheric-origin contribution in a vertical profile of ozone.

15 The development of Lagrangian calculations to reconstruct stratospheric-origin ozone fields is based on the observation that a stratospheric intrusion can retain a chemical signature of its origin for longer than its thermodynamic signature (Bithell et al., 2000). Recent applications of the Reverse Domain Filling (RDF) technique have focused on stratosphere-troposphere exchange (Beuermann et al., 2002; Legras et al., 2003 ; Hegglin et al., 2004; Brioude et al., 2006) and on mixing processes (Methven et al., 2003), and have shown the usefulness of this technique. Here, we use such a method to reconstruct the stratospheric-origin ozone along the MOZAIC profile. The reconstruction method uses the sets of 20000 particles equally distributed in boxes along the aircraft profile and backward trajectories computed for ten days and for each 25 particle. At a given date within the backward period of time, locations of particles on their back trajectories are used to prescribe the ozone mixing ratio of the advected particles. The ozone prescription is made using the stratospheric ozone tracer outputs of the forward run at the same date. It will be shown that the method of coupling forward and backward runs allows for the detection of stratospheric origin of air parcels

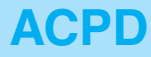

$7,1119-1142,2007$

Tropospheric layering

J. Brioude

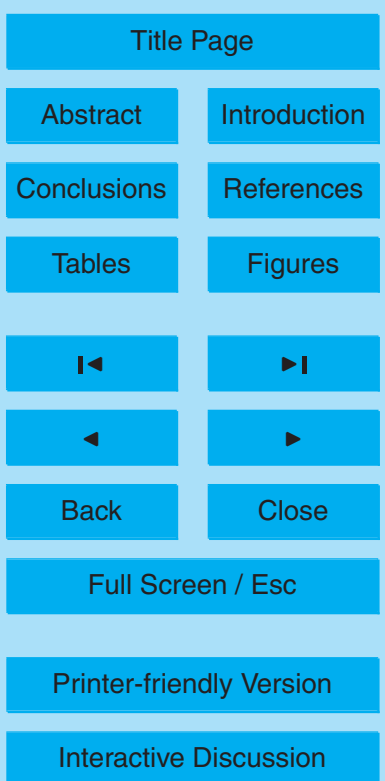

EGU 
beyond a few days. We assume that the ozone mixing ratio prescribed to each particle is advected passively during the reconstruction time-period. Bithell et al. (2000) have shown that a stratospheric intrusion can retain a chemical signature of its origin for longer than its thermodynamic signature. The reconstructed ozone value for a box 5 along the aircraft path that is obtained from this technique is computed by averaging the prescribed ozone tracer mixing ratios of the subset of initial particles. To better ensure the stratospheric-origin character of the reconstructed ozone, only particles having a final location of back trajectory higher than $5 \mathrm{~km}$ altitude are considered. This reconstructed profile, called the RDF-ozone profile, takes account of the stratospheric 10 origin of particles and of their mixing within the troposphere. However, it does not take account for a tropospheric background that may eventually be added to reconstruct a total ozone profile. Validation of the proposed method mainly lies on its ability to reconstruct the ozone profile. In addition, the stratospheric-origin of the layer detected with this method will be illustrated in a dynamical context across the life cycle of the surface 15 cyclone that gives birth to it.

\subsection{MOZAIC observations}

Since 1994 the MOZAIC program (Marenco et al., 1998) has equipped 5 commercial airliners with instruments to measure ozone, water vapour, and carbon monoxide (since 2001). One aircraft carries an additional instrument to measure total odd ni20 trogen (since 2001). Measurements are taken from take-off to landing. Based on the dual-beam UV absorption principle (Thermo-Electron, Model 49-103), the ozone measurement accuracy is estimated at $\pm[2 \mathrm{ppbv}+2 \%]$ for a 4 s response time (Thouret et al., 1998). Based on an infrared analyser, the carbon monoxide measurement accuracy is estimated at $\pm 5 \mathrm{ppbv} \pm 5 \%$ (Nédélec et al., 2003) for a 30s response time.

25 For water vapour, a special airborne humidity sensing device is used for measuring relative humidity and temperature of the atmosphere (Helten et al., 1998). Measurements of total odd nitrogen (not used here) are described in Volz-Thomas et al. (2005). Measurements for more than 26000 long-haul flights are recorded in the MOZAIC data

Tropospheric layering

J. Brioude

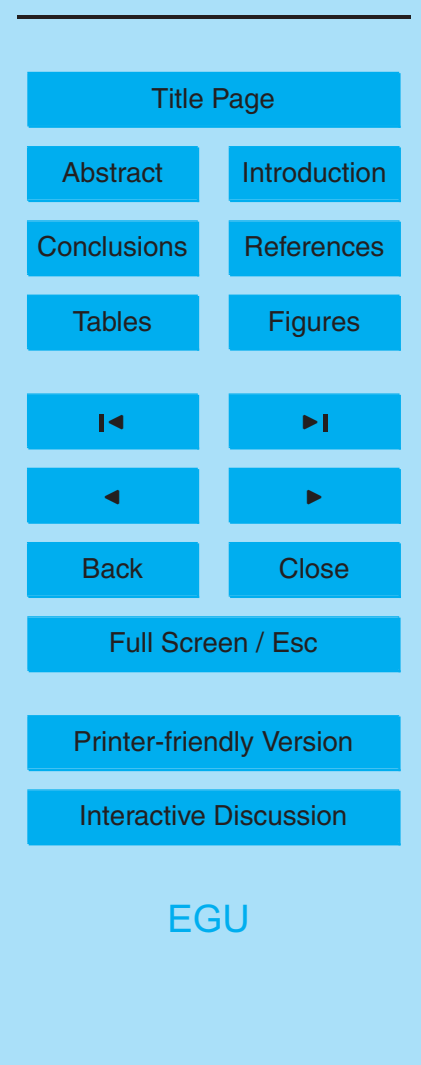


base (http://mozaic.aero.obs-mip.fr/web/) that is opened for scientific use.

Observations of ozone, $\mathrm{CO}$ and relative humidity along a near vertical profile measured by a MOZAIC aircraft descending to Frankfurt on 10 February 2002 at about 12:00 UTC are shown in Fig. 1a. The date of this observation is defined as the time 5 origin for the following backward trajectories and residence time calculations. A layer (called WCB1, cf Fig. 1a) lying between 5.5 and $9 \mathrm{~km}$ is characterized by a constant ozone concentration of $50 \mathrm{ppbv}$ and a constant CO concentration of $140 \mathrm{ppbv}$. A layer (called WCB2, cf Fig. 1a) lying between 2.5 and $4 \mathrm{~km}$ is characterized by relatively constant ozone concentration of $55 \mathrm{ppbv}$ and constant CO concentration of $150 \mathrm{ppbv}$. A 10 very dry and ozone-rich layer (called FOLD1) lies at $5 \mathrm{~km}$. In FOLD1, relative humidity decreases to 10 percent, $\mathrm{CO}$ decreases to $120 \mathrm{ppbv}$, while ozone mixing ratio exceeds $95 \mathrm{ppbv}$. Anticorrelations between ozone and relative humidity, and between ozone and CO in FOLD1 are evidence of a stratospheric intrusion. Though much less pronounced as for FOLD1, anticorrelations signatures between ozone and $\mathrm{CO}$ are also

15 visible in a layer lying at $2.3 \mathrm{~km}$ (called FOLD2, cf Fig. 1a). However, evidence of a stratospheric origin for FOLD2 is too small at this stage to disregard any other origin without a detailed study.

\section{Results}

\subsection{Tropospheric layering}

20 Figures 7, 8 and 9 of Nedelec at al. (2003) describe the synoptic structure of FOLD1 (Fig. 1a) on tropopause and isentropic maps as well as in a vertical cross section. It is an advected layer of stratospherically enhanced air that was introduced in a tropopause fold. Assuming that the mixing ratio of ozone and of $\mathrm{CO}$ inside the fold results linearly from a mixing of stratospheric and tropospheric air, the latter authors estimated that about $20 \%$ of the air inside FOLD1 comes from the stratosphere. Derived from FLEXPART calculations, the ST percentage valid 2 days prior to the observation (Fig. 1b)
ACPD

7, 1119-1142, 2007

Tropospheric layering

J. Brioude

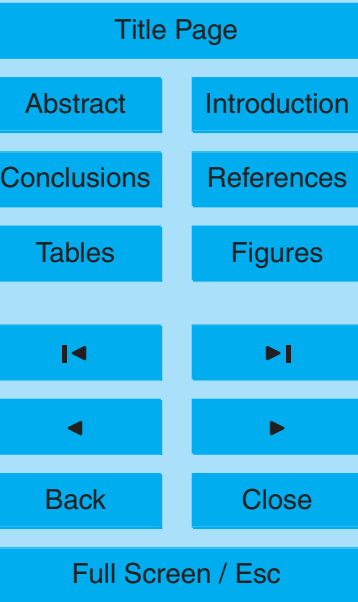

Printer-friendly Version

Interactive Discussion 
ranges from $10 \%$ to $15 \%$ in FOLD1. In agreement with Nedelec et al. (2003), it confirms both the stratospheric origin and the mixing with tropospheric air for FOLD1. Within the time period of 10 days for backward trajectories, the time series of the ST percentage associated with FOLD1 (not shown) indicates that FOLD1 is a rather young strato5 spheric intrusion with a residence time in the troposphere of about 2 days. In WCB1 (Fig. $1 \mathrm{~b}$ ), the $\mathrm{BL}$ tracer valid 2 days prior to the observation ranges from $50 \%$ to $65 \%$. It mainly implies the origin of WCB1 in the planetary boundary layer. The positions of particles of WCB1 2 days prior to the observation are plotted on a composite image of water vapor radiance from GEOS-East and METEOSAT, and with the ECMWF 10 geopotential field at $1000 \mathrm{hPa}$ (Fig. 2a). At that time, particles of WCB1 are located in the warm sector of a maritime cyclone. Later on, as the surface cyclone intensifies and moves northeastward, particles of WCB1 enter in the warm conveyor belt of that cyclone and ascend in the free troposphere.

The residence time of particles of WCB1 in the free troposphere is about two days. 15 It includes the transport by the WCB and by the upper-tropospheric ridge ahead of the surface cyclone. Ascending trajectories of the WCB1 particles interleave over the subsiding trajectories of the FOLD1 particles over Frankfurt.

The $\mathrm{BL}$ tracer associated with WCB2 is shown 5.75 days prior to the observation (Fig. 1b). It ranges from $50 \%$ to $55 \%$, mainly implying a planetary boundary layer origin. Positions of WCB2 particles at that time are presented on the composite picture made with satellite radiances and the 1000-hPa geopotential field (Fig. 2b). The group of particles of WCB2 that is located south of Newfoundland is embedded in the WCB of a surface cyclone growing along the East Coast of USA. Its residence time in the free troposphere, after extraction from the marine boundary layer and up to the time of observation in Frankfurt, is about 5 days. East of Newfoundland, backward trajectories show a second group of particles associated with WCB2. This group has not been embedded in a WCB during its life cycle and participates in the mixing of WCB2.

With regard to FOLD2, ST percentages computed all along the 10-day period used for backward trajectories are always very weak. Examples valid 2 days and 5.75 days
ACPD

7, 1119-1142, 2007

Tropospheric layering

J. Brioude

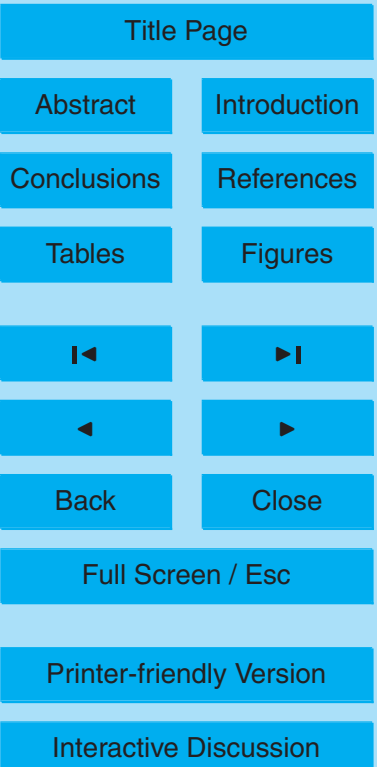

EGU 
prior to the observation time are shown on Fig. 1. The investigation of a possible stratospheric-origin of FOLD2 continues in the section below in which a clustering method is used to better characterize the life cycle of some of the FOLD2 particles.

\subsection{Capture of stratospheric-origin signatures}

5 At a time of 6.75 days prior to the MOZAIC observations, the retroplume initialized with particles in the FOLD2 layer (colored contours on Fig. 3a) shows a large geographical dispersion from $50^{\circ} \mathrm{W}$ to $100^{\circ} \mathrm{W}$. This retroplume is composed of three main groups of particles. The first group lies between 0.5 and $5 \mathrm{~km}$ altitude and stretches along the eastern coast of north America (centre at about $60^{\circ} \mathrm{W}-50^{\circ} \mathrm{N}$, see red and green contours). The second group lies between 3 and $10 \mathrm{~km}$ altitude west and south-west of the Great Lakes (red and black contours). The third group lies between 5 and $10 \mathrm{~km}$ altitude west of Hudson Bay (black contours). The 5-km stratospheric-ozone tracer, based on the Flexpart run in the forward mode and used to prescribe the ozone mixing ratio of advected particles of stratospheric-origin, is shown on Fig. 3a (see the colored field). It shows the structure of a wave in the mid-troposphere.

According to the method to prescribe an ozone mixing ratio to stratospheric-origin particles, it can be seen on Fig. 3b that none of the particles of the first group of the FOLD2 retroplume is associated with a possible stratospheric-origin. However, the second and third groups of the FOLD2 retroplume have got a stratospheric-origin. Particles of stratospheric-origin associated with the second group of the FOLD2 retroplume lie at the eastern tip of a dry band in the water vapour image (Fig. 3b) They belong to the upper-level dynamical precursor that triggers the development of the surface low involved in the formation of the WCB2 layer (see Fig. 2b). One of the ten clusters of the FOLD2 retroplume which is valid at the same date has an altitude of $4.7 \mathrm{~km}$, a PV of $1.4 \mathrm{pvu}$, a relative humidiy of $25 \%$ and a mass fraction of $3 \%$. The characteristics of that cluster at that date (i.e. relatively high PV and low relative humidity) and its position in the dry airstream again confirm the involvment of some of the particles of the second group of the FOLD2 retroplume in a stratospheric intrusion process. Finally, in the

Tropospheric layering

J. Brioude

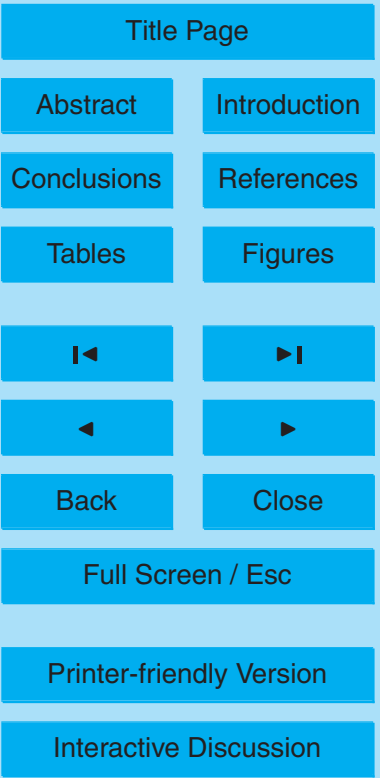


frame of the stratospheric-ozone tracer, the stratospheric ozone vertical cross section on Fig. $3 c$ confirms that this cluster lies in an ozone structure (with an ozone mixing ratio of about $90 \mathrm{ppbv}$ ) that illustrates the presence of an upper level trough.

The third group of the FOLD2 retroplume, which has been shown to be of 5 stratospheric-origin, lies in a large tropopause disturbance as indicated by the dry areas on the water vapor satellite image (Fig. 3b). In the course of the development of the surface low associated with the FOLD2 and WCB2 features, particles of the third group of the FOLD2 retroplume will finally catch up and merge with particles of the second group. The stratospheric intrusion process is shown at a later time period, i.e. 5.75 days 10 (Fig. 2b) and 4.75 days (Fig. 4) prior to the MOZAIC observations. The stratospheric ozone tracer (Fig. 4a) fills up the two dry airstreams associated with the development of the surface low. The RDF-ozone field shows that only the northern dry airstream is associated with the development of FOLD2. Note that because of the descent of the stratospheric intrusion, both the stratospheric ozone tracer and the RDF-ozone fields were shown at $4 \mathrm{~km}$ altitude. To complete the documentation of the life cycle of FOLD2, the RDF-ozone relative to FOLD2 is shown on Fig. $2 \mathrm{~b}$ at the time of extraction of the WCB2 particles out of the marine boundary layer into the free troposphere, i.e. 5.75 days prior to the observations. Again, the position of the RDF-ozone feature in the dry air stream of the surface low is an evidence of stratospheric-origin of FOLD2.

\subsection{Reconstruction of the ozone profile}

In this section, we use the FLEXPART RDF-ozone simulation to reconstruct the ozone profile over Frankfurt, and to assess the residence time of the tropopause fold FOLD2 in the troposphere. The reconstruction of the RDF-ozone values along the MOZAIC profile is based on the initialisation of the stratospheric ozone tracer above $7 \mathrm{~km}$ al25 titude to only take into account stratospheric features in the UTLS domain. Figure 5 shows ozone measurements and RDF-ozone values plotted along the MOZAIC profile. RDF-ozone values are derived from backward trajectories valid 7.5 days prior to the measurements. At the altitude of FOLD1, the MOZAIC ozone peak coincides with a

\section{Tropospheric} layering

J. Brioude

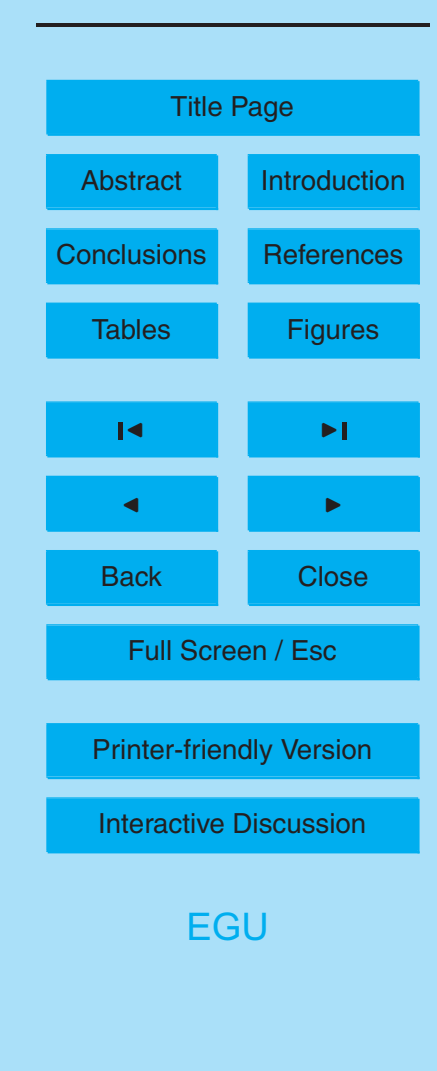


RDF-ozone peak of $55 \mathrm{ppbv}$, which confirms its stratospheric origin. On the lower part of the profile, though the RDF-ozone is weak, a maximum of 3 ppbv coincides with the FOLD2 layer. It constitutes a signature of the stratospheric-origin of FOLD2. The RDFozone peak is smaller and broader than the ozone peak from measurements. The use

5 of analyzed fields can result in an overestimation of mixing between air masses (Stohl et al., 2004). The parametrization of turbulence into the model can also contribute to spread the peak. Such a stratospheric signature in the RDF-ozone simulation lasts during the period from 6.5 to 7.5 days prior to the measurements. An assessment of the residence time of tropopause fold FOLD2 into the tropopshere is therefore about 106.5 days. Finally, the RDF-ozone technique has allowed us to attribute a stratosphericorigin to FOLD2, and to assess a residence time in the troposphere of about 6.5 days. This residence time is also characteristics of the period of time for a complete mixing of the stratospheric-origin layer into the troposphere because FOLD2 can be considered as a very weak ozone anomaly ( +8 ppbv compared to the tropospheric background on 15 the vertical profile) that will likely disappear by venting and turbulence effects at the top of the boundary layer.

\section{Conclusions}

A lagrangian analysis has been made with the FLEXPART Lagrangian particle dispersion model to characterize the tropospheric layering revealed by a vertical profile of ozone, carbone monoxide and relative humidity observed over Frankfurt (Germany) by one of the commercial airliner participating to the MOZAIC programme. It demonstrates the interleaving along the vertical profile of 4 coherent airstreams, two warm conveyor belts and two tropopause folds, that are characteristic of the dynamics of mid-latitude extratropical lows. Layers associated with the two warm conveyor belts are centred at $3 \mathrm{~km}$ and $7 \mathrm{~km}$ altitude. They are relatively thick ( 2 to $3 \mathrm{~km}$ in altitude) and they mainly constitute the tropospheric background for ozone ( $50 \mathrm{ppbv}$ ) and for carbon monoxide ( $90 \mathrm{ppbv}$ ) at the time of the vertical profile observed over Frankfurt.

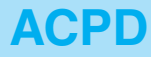

$7,1119-1142,2007$

Tropospheric layering

J. Brioude

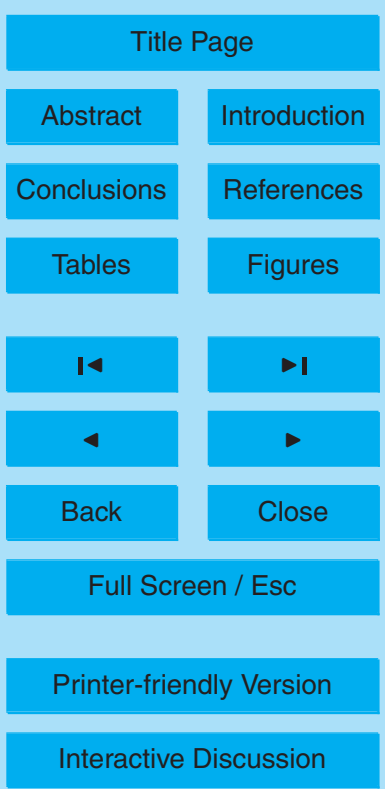


They are representative of particles being extracted from the maritime boundary layer into the free troposphere by warm conveyor belts ahead of surface cold fronts over the Atlantic. According to Flexpart simulations, their residence time into the troposphere range from 2 to 5.75 days. The first tropopause fold is observed at $4.7 \mathrm{~km}$ altitude. It is 5 about $1 \mathrm{~km}$ deep and has retained strong stratospheric-origin signatures, i.e. $95 \mathrm{ppbv}$ for ozone, $70 \mathrm{ppbv}$ for carbon monoxide and $10 \%$ for relative humidity. The residence time of the fold into the troposphere is about 2 days at the time of the observation. The second tropopause fold is a few hundred metres deep and is observed at $2.2 \mathrm{~km}$ altitude just above the planetary boundary layer. Stratospheric-origin signatures are 10 very weak and mainly consist in the anti-correlation of relative anomalies of ozone and carbone monoxide volume mixing ratios ( $+8 \mathrm{ppbv}$ and $-5 \mathrm{ppbv}$, respectively) compared to the tropospheric background. According to the Flexpart simulations, its residence time into the free troposphere is about 6.5 days as the folding process occured over northeastern America. This period of time is also representative of the time scale for a complete mixing of the tropopause fold into the troposphere.

The interests for such a case study are to illustrate in a Lagrangian context the diverse origin of laminae. The free troposphere of this case study is characterized by four interleaved layers which were processed by coherent airstreams coming from frontal systems. This case study exemplifies the diverse origin that may be ascribed to the ubiquitous tropospheric laminae identified by Newell et al. (1999).

A Reverse Domain Filling technique, combining a simulation of stratospheric ozone in a forward mode and back trajectories, has been proposed to prescribe ozone mixing ratio to stratospheric-origin particles.

Our method has been successfully used to demonstrate the stratospheric-origin of 25 the two tropopause folds and to lengthen the period of time on which to assess the residence time of stratospheric intrusions into the troposphere. This method can retrieve the decay of the tropopause fold in the troposphere during 6.5 days, which allow us to characterize a 6.5-day stratospheric intrusion along a vertical profile only by the use of a reconstructed stratospheric tracer concentration. We plan to use such a technique for

\section{Tropospheric} layering

J. Brioude

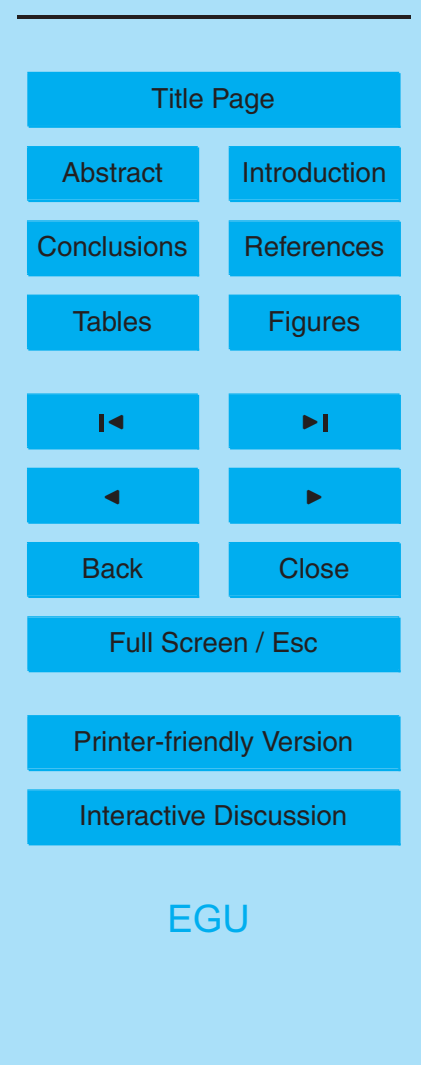


systematic application on the MOZAIC data base which contains more than 28000 vertical profiles from 1994 to 2006, as tentatively begun by Zbinden et al. (2006). It would allow a climatological characterization of the layering structure of the troposphere and improvments in the assessment of the contribution of the stratospheric flux on the tro5 pospheric ozone budget

Acknowledgements. Satellite data were provided by the SATMOS service (http://www. satmos-meteo.fr/) and by O. Cooper (NOAA, Boulder). The authors acknowledge the European Communities and EADS-Airbus for their strong support to the MOZAIC programme, and the particpating airlines (Lufthansa, Austrian, Air France) for the transport and the maintennace of the equipment free of charge since 1994.

\section{References}

Appenzeller, C., Holton, J. R., and Rosenlof, K. H.: Seasonal variation of mass transport across the tropopause, J. Geophys. Res., 101(D10), 15 071-15078, 1996.

Beuermann, J., Konopka P., Brunner D., Bujok O., Gunther O., McKenna D.S., Lelieveld J., Muller R., and Schiller C.: Highresolution measurements and simulation of stratospheric and tropospheric intrusions in the vicinity of the polar jet stream, Geophys. Res. Lett., 29(12), 1577, doi:10.29/2001GL014162, 2002.

Bithell, M., Gray, L .J., and Cox, B. D.: A three-dimensional view of the evolution of midlatitude stratospheric intrusions, J. Atmos. Sci., 56, 673-687, 1999.

20 Bithell, M., Vaughan, G., and Gray, L. J.: Persistence of stratospheric ozone layers in the troposphere, Atmos. Environ., 34(16), 2563-2570, 2000.

Brioude J., Cammas, J.-P., and Cooper O. R.: Stratosphere-troposphere exchange in a summertime extratropical low: analysis, Atmos. Chem. Phys., 6, 2337-2353, 2006, http://www.atmos-chem-phys.net/6/2337/2006/.

Colette, A. and Ancellet, G.: Impact of vertical transport processes on the tropospheric ozone layering above Europe. Part II: Climatological analysis of the past 30 years, Atmos. Env., 39, 5423-5435, 2005.

Cooper, O. R., Moody, J. L., Davenport, J. C., Oltmans, S. J., Johnson, B. J., Chen, X., Shepson, P. B., and Merrill, J. T.: Influence of springtime weather systems on vertical ozone

Tropospheric layering

J. Brioude

Title Page

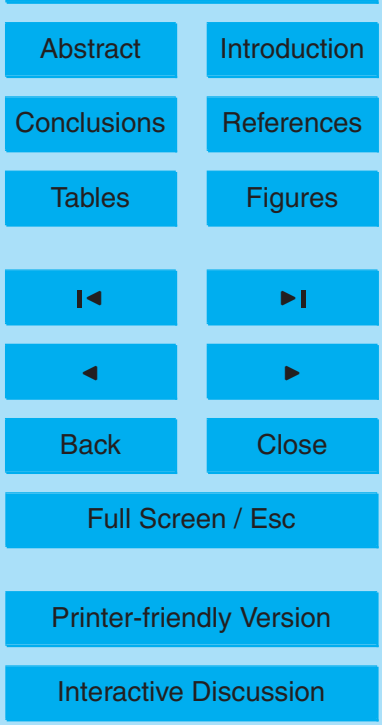


distributions over three North American sites, J. Geophys. Res., 103(D17), 22 001-22 013, 1998.

Cooper, O. R., Moody, J. L., Parrish, D. D., Trainer, M., Ryerson, T. B., Holloway, J. S., Hubler, G., Fehsenfeld, F. C., Oltmans, S. J., and Evans, M. J.: Trace gas signatures of the airstreams

5 within North Atlantic cyclones: Cases Studies from the North Atlantic Regional Experiment (NARE'97) aircraft intensive, J. Geophys. Res., 106(D6), 5437-5456, 2001.

Cooper, O. R., Moody, J. L., Parrish, D. D., Trainer, M., Ryerson, T. B., Holloway, J. S., Hubler, G., Fehsenfeld, F. C., and Evans, M. J.: Trace gas composition of midlatitude cyclones over the western North Atlantic Ocean: A conceptual model, J. Geophys. Res., 107(D7), 4056, doi:10.1029/2001JD000901, 2002a.

Cooper, O. R., Moody, J. L., Parrish, D. D., Trainer, M., Holloway, J. S., Hubler, G., Fehsenfeld, F. C., and Stohl, A.: Trace gas composition of mid-latitude cyclones over the western North Atlantic Ocean: A seasonal comparison of ozone and CO, J. Geophys. Res., 107(D7), 4057, doi:10.1029/2001JD000902, 2002b.

Cooper, O. R., Forster, C., Parrish, D., Dunlea, E., Hubler, G., Fehsenfeld, F., Holloway, J., Oltmans, S., Johnson, B., Wimmers, A., and Horowitz, L.: On the life-cycle of a stratospheric intrusion and its dispersion into polluted warm conveyor belts, J. Geophys. Res., 109, D23S09, doi:10.1029/2003JD004006, 2004.

Cooper, O. R., Stohl, A., Hubler, G., Hsie, E. Y., Parrish, D. D., Tuck, A. F., Kiladis, G. N., Oltmans, S. J., Johnson, B. J., Shapiro, M., Moody, J. L., and Lefohn, A. S.: Direct transport of midlatitude stratospheric ozone into the lower troposphere and marine boundary layer of the tropical Pacific Ocean, J. Geophys. Res., 110, D23310, doi:10.1029/2005JD005783, 2005.

Curtius, J., Sierau, B., Arnold, F., de Reus, M., Ström, J., A. Scheeren, H., and Lelieveld, J.: Measurement of aerosol sulfuric acid 2. Pronounced layering in the free troposphere during the second Aerosol Characterization Experiment (ACE 2), J. Geophys. Res., 106(D23), 31 975-31 990, doi:10.1029/2001JD000605, 2001.

Danielsen, E. F.: Stratospheric-tropospheric exchange based upon radioactivity, ozone and potential vorticity, J. Atmos. Sci., 25, 502-518, 1968.

30 Eckhardt, S., Stohl, A., Wernli, H., James, P., Forster, C., and Spichtinger N.: A 15-Year climatology of Warm Conveyor Belts, J. Climate, 17, 218-237, 2004.

Emanuel, K. A. and Zivkovic-Rothman, M.: Development and evaluation of a convection scheme for use in climate models, J. Atmos. Sci., 56, 1766-1782, 1999.
ACPD

7, 1119-1142, 2007

Tropospheric layering

J. Brioude

Title Page

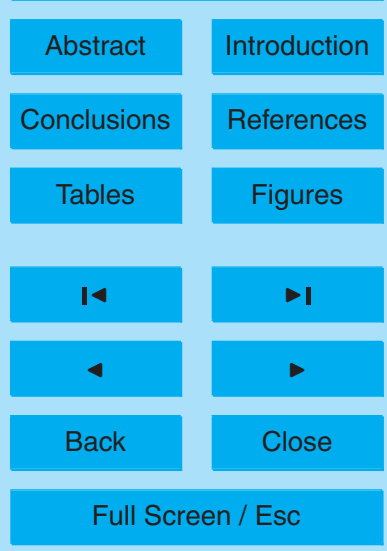

Printer-friendly Version

Interactive Discussion 
Esler, J. G., Tan, D. G. H., Haynes, P. H., Evans, M. J., Law, K. S., Plantevin, P. H., and Pyle, J. A.: Stratosphere-troposphere exchange: Chemical sensitivity to mixing, J. Geophys. Res., 106(D5), 4717-4731, doi:10.1029/2000JD900405, 2001.

Esler, J. G., Haynes, P. H., Law, K. S., Barjat, H., Dewey, K., Kent, J., Schmitgen, S., and Brough, N.: Transport and mixing between airmasses in cold frontal regions during Dynamics and Chemistry of Front Zones (DCFZ), J. Geophys. Res., 108(D4), 4142, doi:10.1029/2001JD001494, 2003.

Forster, C. and Wirth, V.: Radiative decay of idealized stratospheric filaments in the troposphere, J. Geophys. Res., 105, 10169-10 184, 2000.

10 Gray L. J., Bithell, M., and Cox, B. D.: The role of specific humidity fields in the diagnosis of stratosphere troposphere exchange, Geophys. Res. Lett., 21, 2103-2106, 1994.

Hegglin, M. I., Brunner, D., Wernli, H., Schwierz, C., Martius, O., Hoor, P., Fischer, H., Parchatka, U., Spelten, N., Schiller, C., Krebsbach M., Weers, U., Staehelin, J., and Peter, Th.: Tracing troposphere-to-Stratosphere transport above a mid-latitude deep convective system, Atmos. Chem. Phys., 4, 741-756, 2004, http://www.atmos-chem-phys.net/4/741/2004/.

Legras B., Joseph B., and Lefevre F.: Vertical diffusivity in the lower stratosphere from Lagrangian back-trajectory reconstructions of ozone profiles, J. Geophys. Res., 108(D18), 4562, doi:10.1029/2002JD003045, 2003.

Mahfouf J.-F. and Rabier, F.: The ECMWF operational implementation of four dimensional variational assimilation. Part II: Experimental results with improved physics, Quart. J. Roy. Meteorol. Soc., 126, 1171-1190, 2000.

Marenco, A., Thouret, V., Nedelec, P., Smit, H., Helten, M., Kley, D., Karcher, F., Simon, P., Law, K., Pyle, J., Poschmann, G., Von Wrede, R., Hume, C., and Cook, T.: Measurement of ozone and water vapor by Airbus in-service aircraft: The MOZAIC airborne program, An overview, J. Geophys. Res., 103, 25 631-25642, 1998.

Methven, J., Arnold, S. R., O Connor, F. M., Barjat, H., Dewey, K., Kent, J., and Brough, N.: Estimating photochemically produced ozone throughout a domain using flight data and a Lagrangian model, J. Geophys. Res., 108(D9), 4271, doi:10.1029/2002JD002955, 2003.

30 Nedelec, P. , Cammas, J. -P., Thouret, V., Athier, G., Cousin, J. -M., Legrand, C., Abonnel, C., Lecoeur, F., Cayez, G., and Marizy, C.: An improved infrared carbon monoxide analyser for routine measurements aboard commercial Airbus aircraft: technical validation and first scientific results of the MOZAIC III programme, Atmos. Chem. Phys., 3, 1551-1564, 2003,

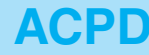

$7,1119-1142,2007$

Tropospheric layering

J. Brioude

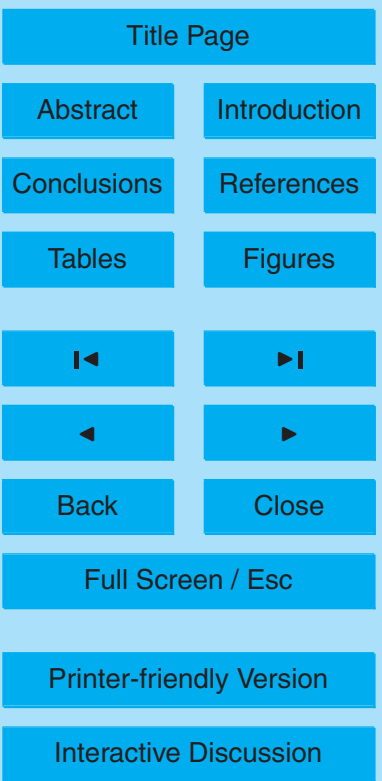


http://www.atmos-chem-phys.net/3/1551/2003/.

Newell, R. E., Thouret, V., Cho, J. Y. N., Stoller, P., Marenco, A., and Smit, H. G.: Ubiquity of quasi-horizontal layers in the troposphere, NATURE, 398, 316-319 doi:10.1038/18,642, 1999.

5 Rabier, F., Jarvinen, H., Klinker, E., Mahfouf, J.-F., and Simmons, A.: The ECMWF operational implementation of fourdimensional variational assimilation. Part I: Experimental results with simplified physics, Quart. J. Roy. Meteorol. Soc., 126, 1143-1170, 2000.

Shapiro, M. A.: Further evidence of the mesoscale and turbulent structure of upper level jet stream-frontal zone systems/ Mon. Wea. Rev., 106, 1100-1111, 1978.

10 Shapiro, M. A.: Turbulent mixing within tropopause folds as a mechanism for the exchange of chemical constituents between the stratosphere and troposphere, J. Atmos. Sci., 37, 994$1004,1980$.

Stohl, A. and Thomson, D. J.: A density correction for Lagrangian particle dispersion models, Boundary Layer Meteorol., 90, 155-167, 1999.

Stohl, A. and Trickl, T.: A textbook example of long-range transport: Simultaneous observations of ozone maxima of stratospheric and North American origin in the free troposphere over Europe, J. Geophys. Res., 104(30), 445-462, 1999.

Stohl, A., Spichtinger-Rakowsky, N., Bonasoni, P., Feldmann, H., Memmesheimer, M., Scheel, H. E., Trickl, T., Hbener, Hubener, S., Ringer, W., and Mandl, M.: The influence of strato20 spheric intrusions on alpine ozone concentrations, Atmos. Environ., 34, 1323-1354, 2000.

Stohl, A.: A one year Lagrangian climatology of airstreams in the Northern Hemisphere troposphere and lowermost stratosphere, J. Geophys. Res., 106, 7263-7279, 2001.

Stohl, A., Eckhardt, S., Forster, C., James, P., Spichtinger, N., and P.,: A replacement for simple back trajectory calculations in the interpretation of atmospheric trace substance measurements, Atmos. Environ. 36, 4635-4648, 2002.

Stohl, A., Bonasoni, P., Cristofanelli, P., Collins, W., et al.: Stratosphere-Troposphere exchange: A review, and what we have learned from STACCATO, J. Geophys. Res., 108(D12), 8516, doi:10.1029/2002JD002490, 2003.

Stohl, A., Cooper, O. R., and James, P.: A cautionary note on the use of meteorological analysis fields for quantifying atmospheric mixing, J. Atmos. Sci., 61(12), 1446-1453, 2004.

Stohl, A., Forster, C., Frank, A., Seibert, P., and Wotawa, G.: Technical Note : The Lagrangian particle dispersion model FLEXPART version 6.2, Atmos. Chem. Phys., 5, 2461-2474, 2005, http://www.atmos-chem-phys.net/5/2461/2005/.

\section{Tropospheric layering}

J. Brioude

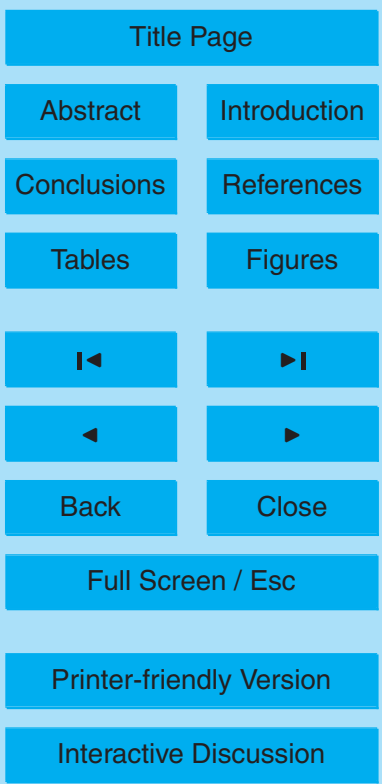


Thouret, V., Marenco, A., Nedelec, P., and Grouhel, C.: Ozone climatologies at 9-12 km altitude as seen by the MOZAIC airborne program between September 1994 and August 1996, J. Geophys. Res., 103, 25653-25679, 1998.

Thouret, V., Cho, J. Y. N., Newell, R. E., Marenco, A., and Smit, H. G. J.: General characteristics of tropospheric trace constituent layers observed in the MOZAIC program, J. Geophys. Res., 105(D13), 17 379-17392, 2000.

Vaughan G., Price, J. D., and Howells, A.: Transport into the troposphere in a tropopause fold, Q. J. R. Meteorol. Soc., 120, 1085-1103, 1994.

Volz-Thomas, A., Berg, M., Heil, T., Houben, N., Lerner, A., Petrick, W., Raak, D., and Patz, $\mathrm{H}$.-W.: Measurements of total odd nitrogen (NOy) aboard MOZAIC in-service aircraft: instrument design, operation and performance, Atmos. Chem. Phys., 5, 583-595, 2005, http://www.atmos-chem-phys. net/5/583/2005/.

Wernli, H. and Davies, H. C.: A Lagrangian-based analysis of extratropical cyclones. I: The method and some applications, Q. J. Roy. Meteorol. Soc., 123, 467-489, 1997.

Wernli, H. and Bourqui, M.: A one-year Lagrangian climatology of (deep) cross-tropopause exchange on the extratropical northern hemisphere, J. Geophys. Res., 107, 4021, doi:10.1029/2001JD000812, 2002.

Zbinden, R. M., Cammas, J.-P., Thouret, V., Nedelec, P., Karcher, F., and Simon, P.: Midlatitude tropospheric ozone columns from the MOZAIC program: climatology and interannual variability, Atmos. Chem. Phys., 6, 1053-1073, 2006,

http://www.atmos-chem-phys.net/6/1053/2006/.

\section{ACPD}

7, 1119-1142, 2007

Tropospheric layering

J. Brioude

Title Page

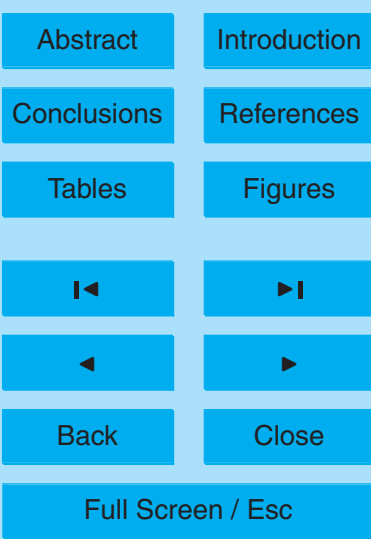

Printer-friendly Version

Interactive Discussion 


\section{ACPD}

$7,1119-1142,2007$

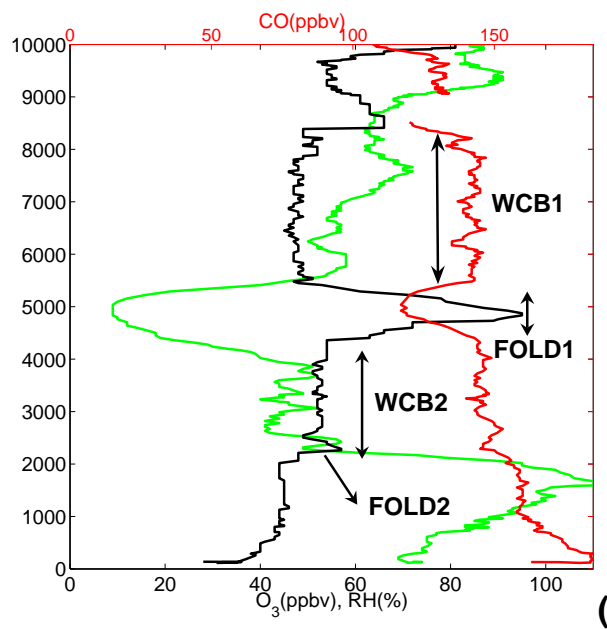

(a)

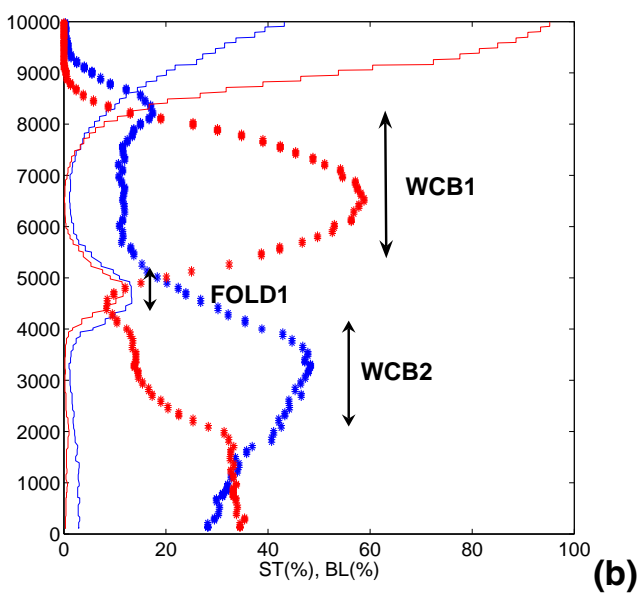

Tropospheric layering

J. Brioude

Fig. 1. (a) MOZAIC vertical profile over Frankfurt on 10 February 2002, 12:00 UTC for ozone (ppbv, black line), CO (ppbv, red line) and relative humidity (\%, green line) versus barometric altitude $(\mathrm{m})$. (b) Fractions of boundary layer (BL) tracer (\%, star) and stratospheric (ST) tracer (\%, line) correspond to the percentage values gained with backward trajectory length of 2 days (in red) and 5.75 days (in blue). Origin of layers denoted WCB1, FOLD1, WCB2 and FOLD2 are discussed in the text. 


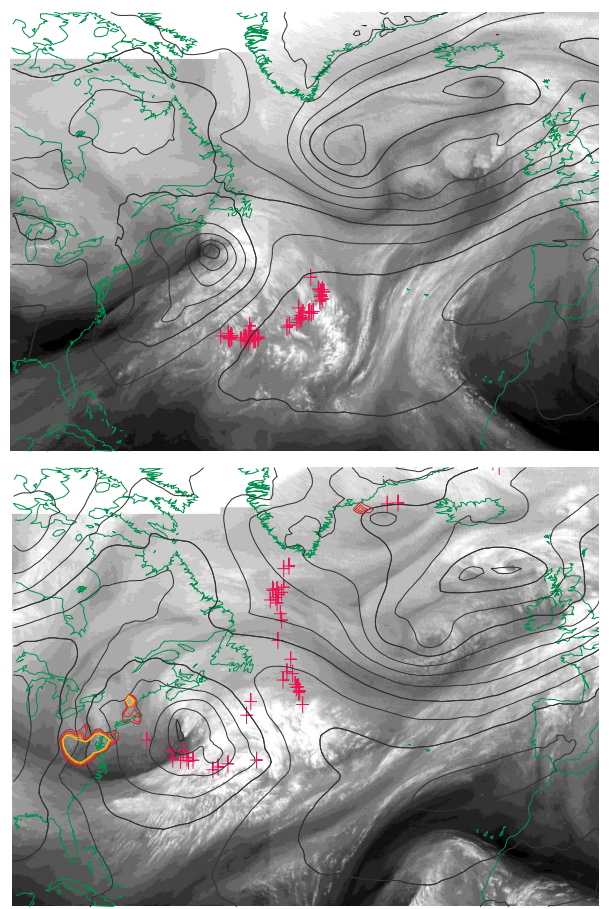

Fig. 2. Composite pictures of water vapour channel radiances (converted in temperatures, $\mathrm{K}$ ) for GOES-EAST and METEOSAT satellites, and 1000-hPa geopotential fields from ECMWF analyses valid on

(a) 8 February, 12:00 UTC (2 days prior to the observation time) and

(b) 4 February, 18:00 UTC (5.75 days prior to the time of observation).

Red crosses depict the end-of-trajectory positions of particles related to layers WCB1 (a) and WCB2 (b) when extracted from the marine boundary layer into the free troposphere. Colored isocontours represent the contribution of the stratospheric ozone tracer $(0.01,0.015,0.02$, 0.025 , and $0.03 \mathrm{ppbv}$ contours) prescribed to the RDF-ozone of layer FOLD2.
ACPD

$7,1119-1142,2007$

Tropospheric layering

J. Brioude

Title Page

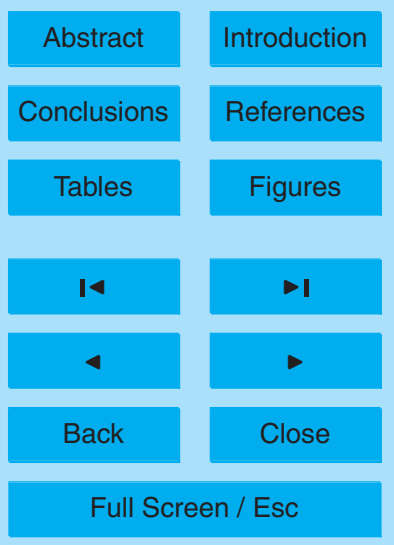

Printer-friendly Version

Interactive Discussion 


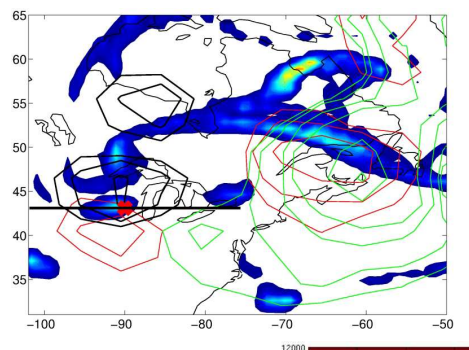

(a)
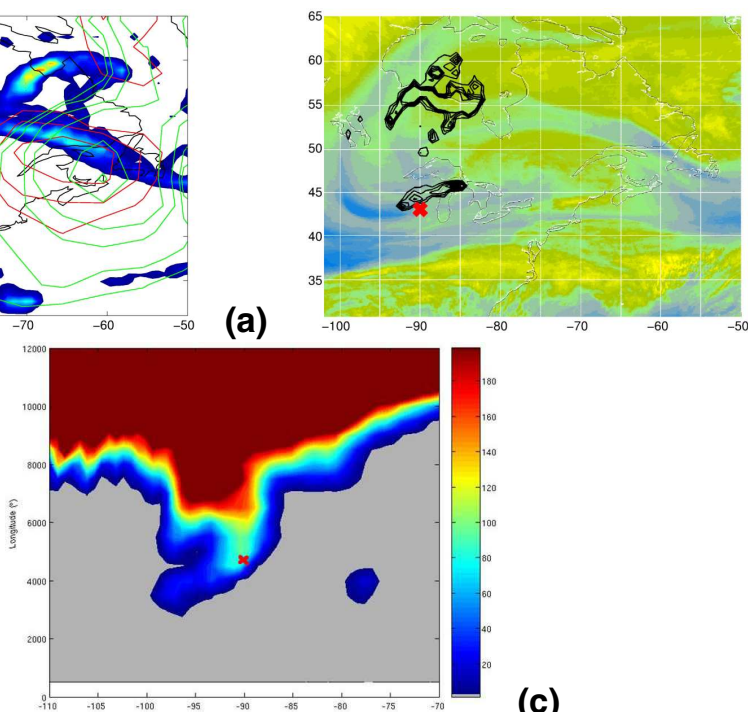

(c) (b)
ACPD

$7,1119-1142,2007$

Tropospheric layering

J. Brioude

Fig. 3. Stratospheric-origin indicators relative to the formation of the FOLD2 layer observed in Frankfurt (Fig. 1). All fields are valid on 3 February, 18:00 UTC (6.75 days prior to the time of observation).

(a) Stratospheric ozone tracer (coloured field, ppbv, colobar in c) at $5 \mathrm{~km}$ altitude as derived from the Flexpart simulation in the forward mode. Contours represent the percentages $(0.05 \%$, $0.1 \%, 0.25 \%, 0.5 \%$, and $1.5 \%$ ) of air particles associated with the retro-plume of the FOLD2 layer. Green, red and black contours are for particles with end-of-trajectory altitudes in the layers $0.5-3 \mathrm{~km}, 3-5 \mathrm{~km}$, and $5-10 \mathrm{~km}$, respectively. The red cross indicates the position of the cluster of particles described in the text.

(b) Radiances in the water vapor channel of GOES-EAST (colored field, K). Black contours represent the contribution of the stratospheric ozone tracer $(0.01,0.015,0.02,0.025$, and 0.03 ppbv contours) prescribed to the RDF-ozone of layer FOLD2.

(c) Vertical-cross section of the stratospheric-ozone tracer derived from the FLEXPART run in forward mode. The trace of the vertical cross-section at the surface is indicated on (a). The red cross represent the position of the cluster of particles described in the text.

Full Screen / Esc

Printer-friendly Version

Interactive Discussion 


\section{ACPD}

$7,1119-1142,2007$

Tropospheric layering

J. Brioude

Title Page

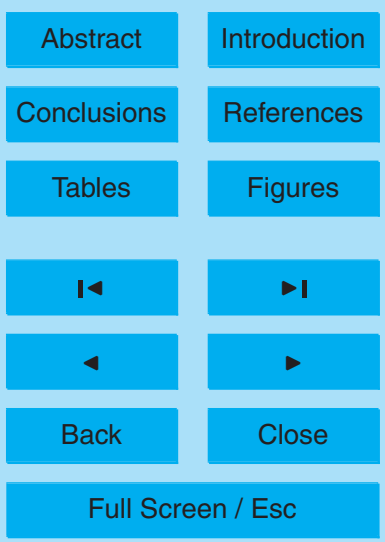

Printer-friendly Version

Interactive Discussion

Fig. 4. GOES-EAST and METEOSAT satellites radiance temperature $(K)$ in the water vapour channel on 5 February, 18:00 UTC (4.75 days prior to the time of observation).

(a) Stratospheric-ozone tracer field (ppbv, colored square) at $4 \mathrm{~km}$ altitude derived from the forward mode of the Flexpart simulation.

(b) Contours represent the contribution of the stratospheric ozone tracer $(0.01,0.015,0.02$, 0.025 , and $0.03 \mathrm{ppbv}$ contours) at $4 \mathrm{~km}$ altitude that is prescribed to the RDF-ozone of layer FOLD2. 


\section{ACPD}

7, 1119-1142, 2007

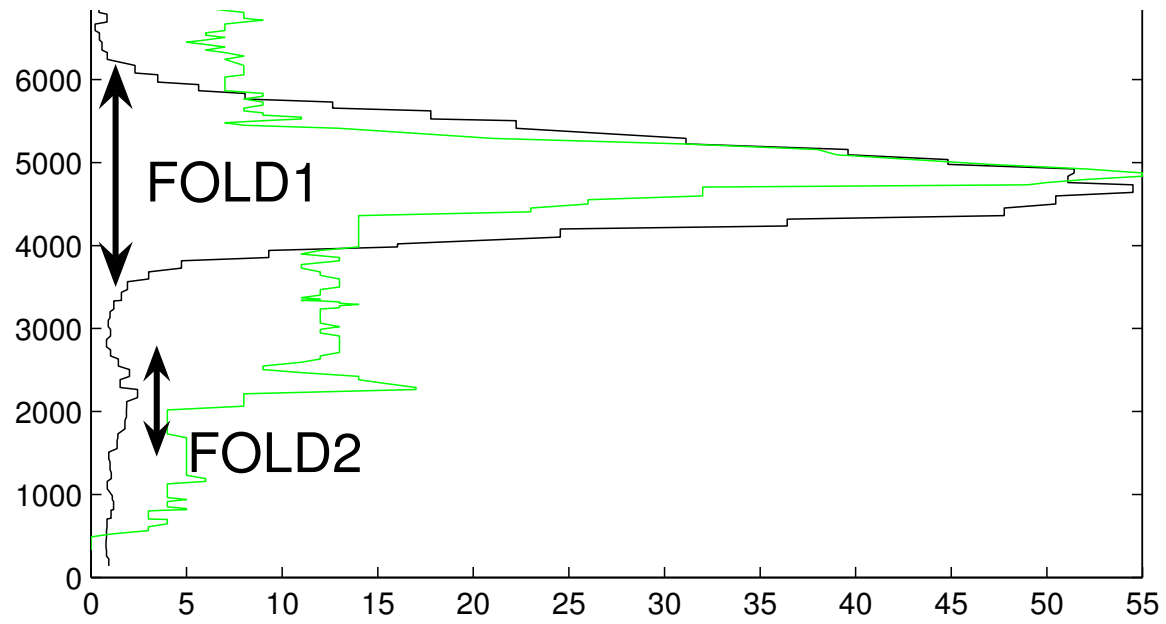

Tropospheric layering

J. Brioude

Title Page

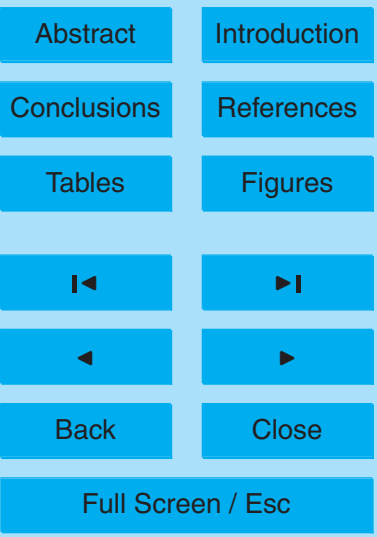

Printer-friendly Version

Interactive Discussion 